\title{
Under the aegis of the saints. Hagiography and power in early Carolingian northern Italy \\ Giorgia Vocino
}

[accepted manuscript of the article published in Early Medieval Europe 22/1 (2014), pp. 26-52

https://doi.org/10.1111/emed.12037]

\begin{abstract}
In the transition from the Lombard to the Carolingian period, hagiography came to play a fundamental role in the strategies of legitimation and representation of the episcopal churches of the regnum Langobardorum. This article gives an overview of the features, choices, tastes and models of sanctity characteristic of Italian hagiography, against the background of local contexts and political competition. It demonstrates that in all of the territories under Frankish rule, hagiography represented a chief instrument in the hands of the ecclesiastical elites to shape and use the past in views of the concerns of the present.
\end{abstract}

\section{A Introduction}

Being both close to God and present on earth, where their remains rest, saints have always played an important role in the world of the living. The possession of a holy body - or just a little portion of it - and the management of the cult around it were, and still are today, instrumental in shaping the political, religious and social balance in a given space. The early Middle Ages provide many examples of politics, saints, and relics tightly connected to one another. ${ }^{1}$ This certainly holds true for the Carolingian 
period when interest in the saints' holy bodies grew, just like the boundaries of the expanding Frankish Kingdom. ${ }^{2}$

The fall of the Lombard capital, the city of Pavia, in 774 and the annexation of the regnum Langobardorum to the Kingdom of the Franks widened the horizon wherein different traditions about the management and promotion of saints' cults met each other. $^{3}$ The Carolingian sovereigns found in the Italian landscape - in Rome, but also in other cities of the peninsula - those resources of the past they deemed necessary for their own legitimation and display of power: these resources, ranging from the written word and architectural monuments to the translation and possession of Roman saints' bones, have been deeply investigated in the last two decades. ${ }^{4}$ The authority of texts in combination with ancient, and prestigious, written traditions - both promoted and supported by the Carolingian rulers from the eight century onwards - found in the Italian Kingdom a very fertile soil: south of the Alps the late antique traditions and cults were still alive, known and cultivated. Both foreign bishops - appointed by the Frankish kings at the head of the most important Italian bishoprics or the prelates of the court on their journey to Rome - and the local elites could draw on this pre-existing material. Another fundamental consequence of the Frankish conquest concerns the political weight of bishops and, thereby, episcopal cities. ${ }^{5}$ The latter were not only ecclesiastical places of power, but key centres for the political government of the former regnum Langobardorum. The authority of bishops in the Italian cities was the result of a long process predating Carolingian times: with the dismantling of the Roman administration, the episcopus had progressively appropriated many of the responsibilities and public duties of the civic elites, the curiales, becoming the leader of the local community. In the Italian landscape, the role of episcopal churches as foci of urban identities is a well 
known phenomenon, one that still retain the interest of early medieval scholars. ${ }^{6}$ While the episcopal dioceses of Central and Southern Italy underwent a traumatic process of redefinition - in some cases resulting in the disappearance of episcopal sees throughout the transition from Late Antiquity to the early Middle Ages (late sixth and early seventh centuries), the episcopal churches of Northern Italy are characterized by a greater continuity. Thence, the political weight granted by the Frankish rulers to bishops met in Italy with a strong episcopal tradition: under the Carolingians, the bishops seating in the cities of the former regnum langobardorum were only strengthening their position as mediators between the political centre and the local elites.

Along with public institutions and offices, episcopal churches and urban monasteries were equally important centres of power where the most eminent local families found parallel or alternative ways to legitimate, promote and represent their role in society. ${ }^{7}$ Therefore, the enhancement of the political prominence of bishops provides a key element in understanding the revival of hagiographical literature in the Italian episcopal scriptoria - which in this case were urban scriptoria -, its spread well beyond the city walls and its use in the political arena. The foreign rulers and the bishops appointed to wield their authority over the Italian churches encountered particularly favourable conditions. They had at their disposal all the means to enhance the prestige of their ecclesia, and along with it also their own authority: the pre-existing traditions in terms of cults and hagiographical literature - already oriented towards the celebration of the local episcopal church - only needed to be readjusted to fit the present needs, claims and ambitions. In that sense, the political change represented by the Carolingian take-over offered new opportunities to redefine the hierarchy and prestige 
of the episcopal churches in the kingdom of Italy, a chance bishops were obviously eager to seize.

In order to be fully understood, the Carolingian hagiography of the Kingdom of Italy needs to be viewed within this more general context, so I will not just address the peculiar traits of the Italian saints' Lives and Passions, but also pay attention, throughout this paper, to the features these texts had in common with the rest of the Carolingian hagiographical literature, as well as to the areas where the Italian corpus reveals itself as quite different.

This article aims at giving a brief overview of the Carolingian hagiography written in the Kingdom of Italy. In the late eighth and early ninth centuries, this region saw what seems to be an explosion of hagiographical writing. Having first analysed the reasons for this phenomenon, I shall then focus on the main choices and strategies featuring in the saints' Lives compiled in northern Italy, arguing that they reflect a highly competitive background and the political changes in the kingdom. In a final section I shall discuss the hierarchy and models of sanctity proposed in the sources, which show both continuities and discontinuities with the pre-Carolingian period.

This general survey cannot be a completely in-depth presentation of the entire hagiographical corpus written in the Italian kingdom. It merely aims to provide the reader with a frame of reference concerning the hagiography of a region that, already in 774 at the time of the Carolingian annexation, boasted a long and prestigious tradition of the cult and promotion of saints. The encounter with the Frankish world - and its models, traditions, preferences, texts and learned men - provided occasion to rethink (and reshape, if necessary) the coordinates of these local cults and traditions. Thus, the 
hagiographical literature written in this period of transition -the late eighth and ninth centuries - may shed light on how, and to what measure, early medieval political change might lead to changing perceptions of the past and its representation for a contemporary audience.

\section{A An explosion of writing: the Carolingian hagiography of the kingdom of Italy}

Late antique Italy saw intense attention given to the promotion and definition of saints' cults. $^{8}$ The death of Gregory the Great in 604, however, ushered in a disheartening silence lasting until the ninth century, which saw the increasing compilation of hagiographical collections (Passionarii), copied and distributed throughout the political and cultural network of Carolingian control. ${ }^{9}$ Dating a Vita or Passio - which can predate the first manuscript evidence by some centuries - is undoubtedly the main challenge for any historian using these sources: hagiographies are usually bare accounts, void of any precise historical and geographical reference to the time of writing. And since they often are literary works by anonymous authors, dating them to an exact moment - sometimes even a specific century - can turn out to be a delicate, if not desperate, operation. But the Carolingian period offers some extra benchmarks when determining the date, place and context of a given hagiography.

The Carolingian correctio of the liturgy also touched hagiographical literature. ${ }^{10}$ The authority of written texts was enhanced, while at the same time greater attention was paid to orthodoxy. The ecclesiastical Council of Frankfurt in 794 summed this up, when it stated: 'That no new saints are to be venerated or invoked, and no shrines for them to be put up along the roads; but those alone are to be venerated in the church who have been deservedly chosen on the basis of their passions or lives'. ${ }^{11}$ New instructions 
were aimed at normalising and defining the hagiographical genre while rejecting brand new saints and any features associated with heterodoxy. A clear example of this process is the expunction of some archaic features, like episodes involving speaking animals. ${ }^{12}$ Furthermore, the cultural network of the Carolingian Empire and its effective communication, facilitated the circulation of relics, scribes, texts, and models alike. ${ }^{13}$ Monastic and episcopal scriptoria, as well as libraries, thus became the most important hubs of this interconnected world: here texts were gathered, ${ }^{14}$ copied and integrated in larger collections both north and south of the Alps. Bobbio, Sant'Ambrogio in Milan, the nunnery of San Salvatore in Brescia and the library of Verona acted as key cultural centres connecting the Kingdom of Italy to the Carolingian heartland - Rome should also be considered as an important junction in this network - and allowing a circulation in both directions. Therefore, it is not surprising that the earliest surviving manuscripts recording new Italian hagiographies come from great royal abbeys such as Reichenau and St Gall. One of the earliest copies of the late eighth- or early ninth-century Vita sanctorum Syri atque Iventii (BHL $7976+4619)^{15}$ is a ninth- or tenth-century codex copied and preserved in St Gall (Stiftsbibliothek, 566). ${ }^{16}$ Likewise, the Passions of the first bishops of Aquileia ${ }^{17}$ circulated north of the Alps soon after their conception: the two earliest manuscripts belong to Bavarian and Alemannian monasteries confirming the existence of an important axis connecting the northeastern regions of Italy with

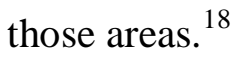

The affirmation of hagiographical texts as a source of authority that could also be relied on in judicial procedure is also one of the results of the Carolingian correctio. ${ }^{19}$ This was the case, for example, when Maxentius, the patriarch of Cividale, appeared before imperial missi, Roman legates, and almost all the bishops of the 
kingdom of Italy in Mantua in 827, in an attempt to be publicly acknowledged as the sole and unique legitimate heir of the ancient metropolitan see of Aquileia. ${ }^{20}$ Maxentius also decided to base his claims against the rival patriarch of Grado on hagiographical material, ${ }^{21}$ presenting the assembled prelates with little books of prayers which included the holy documents certifying his claims (defined in the acts as auctoritates veracissimae): ${ }^{22}$

The most holy man Maxentius, patriarch of Aquileia, coming to that council attended by the most venerable bishops, at the presence of the deacons and the rest of the clergy, brought some little books of prayers to prove the division of his church, in order to obtain that his churches, which the attack of the barbarians set apart from their Mother Church, were brought back now, in time of peace, under his possession according to the authority of the canons: "We who learned in the perfect truth that the church of Aquileia was founded, in the faith of Christ before all the other churches of Italy, by the blessed evangelist Mark, who was the spiritual son born from the holy womb of the font and was well beloved by the apostle St Peter, and also by the most elegant Hermachora. We learned that the church of Aquileia has always watched over the pastoral care, that it was instructed in the doctrines of the holy apostles and of the holy Roman church and that it always was its disciple and special vicar in everything, as we found out in the holy documents of this church of Aquileia. ${ }^{23}$ 
The hagiographical legend connecting the foundation of the episcopal church of Aquileia to the evangelist Mark and to St Peter appeared in writing for the first time in these same years: the correspondence between the vocabulary of the acts of the council of Mantua and the Passio sanctorum Hermachorae et Fortunati (BHL 3838) patently demonstrates the permeability between the public, political and ecclesiastical arena on the one hand and hagiographical literature on the other. ${ }^{24}$ A saint's Life could be presented as an auctoritas in a trial, which served Patriarch Maxentius well, as he succeeded in having his rights temporarily recognised to the expense of the delegate of the Patriarchate of Grado. ${ }^{25}$

In the late eighth and early ninth centuries, influenced by Carolingian notions of correctio, the status of hagiographical accounts in the political and cultural field was gradually growing. Such documents were invested with the authority of three key elements: writing, the past and orthodoxy. In addition, these were documents circulating fast and wide, providing the perfect backing for any strategies of legitimation and persuasion which made hagiography an efficient instrument in the hands of the episcopal churches of the regnum Italiae. These aspects need to be kept in mind when studying the hagiographical literature composed in the Carolingian kingdom of Italy: pre-existing cults and legends were repromoted, and reshaped if need be, through acts of writing with an impact that extended far beyond the confines of the literary genre and liturgical practice. To our modern eye - placed at an enormous, and distorting, distance on the timeline - this phenomenon takes the form of a veritable 'explosion of writing'.

A The choice of the local viri Dei and the taste for the 'history of the origins' 
While the Carolingian period saw a continuous stream of Italian saints' remains to the monasteries and churches north of the Alps - especially of Roman martyrs -, ${ }^{26}$ in the Kingdom of Italy the local bishops showed a marked taste for those local holy men whose relics they owned and whose deeds were tightly entangled with the history of their episcopal see. ${ }^{27}$ Here, relic translations mainly operated at a local scale: saints’ remains were moved from a suburban church to the cathedral, they were transferred within the same diocese or they were exchanged as gifts among neighbouring bishops. ${ }^{28}$ The Italian episcopi seem to hold all the authority necessary for the management, the patronage and, then, the transfer of sacred remains. While north of the Alps, powerful men of the Carolingian entourage - like Einhard or even the powerful archchaplain Hilduin of Saint-Denis ${ }^{29}$ - felt obliged to obtain imperial permission before performing a translatio, ${ }^{30}$ the Italian bishops acted on their own authority, managing relics as they saw fit to enhance their legitimation, or to create new balances of power in the sacred and political geography of the kingdom.

Indeed, in the Kingdom of Italy, viri Dei who were born and raised, and who lived and died in the orbit of the church that possessed their bodies, received the greatest veneration, for these saints were thought to offer the most effective patronage to the local flock. Rampertus, bishop of Brescia between 824/826 and 843/844 and author of the written sermon in commemoration of the translatio of the body of Philastrius of Brescia, made this point very clearly: "We indeed hope to be protected thanks to the credits of all the saints and above all of those whose bodies we cherished and who were born and lived with our forefathers. We are both educated in their doctrine and fortified by the example of their martyrdom ". ${ }^{31}$ 
Even foreign bishops and elites holding positions of power in the kingdom, ${ }^{32}$ adopted this practice: the Frankish Milanese Archbishop Angilbert II (824-859), for instance, embraced and enhanced the local cult and tradition dedicated to Ambrose, establishing the roots for the later affirmation of the metropolitan church of Milan as the ecclesia Ambrosiana. ${ }^{33}$ With the possible exception of Verona, where the sources reveal glimpses of the opposition of the local elites and society against the Alemannian Bishop Ratold (799/802-840), ${ }^{34}$ the Carolingian hagiography of Italy is the expression of local urban and episcopal elites employing cohesive strategies in their struggle for further legitimation.

The special veneration paid to the local saints went hand in hand with the renewed interest in local history: the past and its monuments - surviving buildings from the Roman age and the local Christian heroes alike ${ }^{35}$ - were recalled in order to emphasize the honour, prestige, fame, and legitimacy of the contemporary ecclesia. The importance of a shared vision of the past to Carolingian elites has been stressed in recent works by modern scholars. ${ }^{36}$ This interest in history is also evident in hagiographical literature, with the glorious age of the first martyrs and bishops becoming a magnifying mirror of the present.

An attentive re-reading and re-shaping of the past was necessary for any successful attempt on the part of the episcopal centres of the kingdom of Italy to rise within a strict hierarchy of prestige and power. Whenever the stories of the local martyrs and bishops faded in a foggy past, it was the hagiographer's task to frame it in a precise moment of Christian history. In some cases this operation could lead to the rewriting and correction of the history of the local bishopric. The anonymous author of the Vita sanctorum Syri atque Iventii (BHL 7976+4619) - a text dedicated to the first 
and the third bishop of the former Lombard capital, Pavia - decided to place the blurred origins of the local church in the apostolic age and connected them to the prince of the apostles, St Peter. His omission of any reference to the metropolitan see of Milan, the church that had actually played the main role in the organisation of the first Christian community in Pavia, was indeed a bold move, but one drawing on a preexisting tradition: the legend of the evangelist Mark as a preacher and church founder in Italy. ${ }^{37}$ In the late eighth century, Paul the Deacon had described the apostolic foundations of Italy in his Liber de episcopis Mettensibus. ${ }^{38}$ According to Paul, once St Peter had reached Rome, he decided to evangelise the most important cities of the West by sending out his companions: Apollinaris was then sent to Ravenna, Leucius to Brindisi, Anatolius (or Anatelon) to Milan, and Mark, his first and well-beloved disciple, together with Hermachora to Aquileia. ${ }^{39}$ This legend focusing on Mark’s preaching mission in Italy is not a Carolingian novelty: the Byzantine Emperor Heraclius I (610-641) is said to have sent the throne of St Mark (beatissimi Marci sedis) to the patriarch of Grado, acknowledging the existence of a local tradition considering the evangelist as the founder of the ecclesia Aquileiensis. ${ }^{40}$ The earliest surviving written testimonies celebrating this legend, however, are all Carolingian products: Paul the Deacon's work, the Acts of the Council of Mantua and the hagiographical account dedicated to the Aquileian saints Hermachora and Fortunatus all subscribe to the same tradition. ${ }^{41}$ It is therefore not surprising that an anonymous hagiographer from Pavia, reshaping the local Christian past, chose to attach the origins of the Ticinensis ecclesia to the church of Aquileia and by proxy to the Roman see founded by St Peter. He explicitly stated: 
He (i.e. Mark) established in his place the blessed Hermachora, a man whom Mark himself had trained and educated and who was renowned for his holiness and sagacity. Hermagora's disciples and ministers were the venerable men Syrus and Iventius. And lo, inestimable lucidity poured from the font of light, was drawn into their blessed hearts and set alight the souls of the people of Pavia. It flowed from Christ to Peter, from Peter to Mark, then from Mark to Hermachora, from Hermachora to the most blessed men Syrus and Iventius. Summoning his disciple Syrus, he bestowed upon him the title of bishop and associating to him the blessed Iventius he directed him to Pavia to preach the name of our Lord Jesus Christ. $^{42}$

The history of the local episcopal church experienced an important correction: Pavia was emancipated from the long shadow of the Milanese archbishops ${ }^{43}$ and, at the same time, the city was framed as a member of the network of the oldest and most prestigious bishoprics of Italy, whose political weight could now be challenged. ${ }^{44}$ This legend perfectly fitted the 'Pavese exception', an early medieval local accomplishment, possibly achieved at the end of the seventh century, that allowed the local bishops to be ordained directly by the Roman popes. This fundamental aspect of the episcopal history of Pavia will be further investigated in what follows; for now it should just be noted how the reshaping of the past, along with the celebration of the local history, proved a profitable strategy to give a new and competitive profile to the bishopric in question.

\section{A Reading 'competition' in the strategies of writing}


The writing and the subsequent circulation of a new hagiographical text could be a potent weapon in the hands of a purposeful bishop - for instance, in the case of Maxentius of Aquileia - and ambitious ecclesiastical local elites. Furthermore, a written Life in favour of one church could push another anonymous author of a rival church launch a hagiographical counter-attack. In one of the earliest manuscripts recording the Passio sanctorum Hermachorae et Fortunati (BHL 3838), ${ }^{45}$ we also find the Passio sanctorum Helari et Tatiani (BHL 3881), dedicated to another pair of martyrs, including a bishop, who lived and died in Aquileia. ${ }^{46}$ Like Hermachora and Fortunatus, Saints Helarus and Tatianus are mentioned in the Martyrology of Jerome (Martyrologium Hieronymianum), but here they are recorded simply as martyrs and not as bishops. ${ }^{47}$ In the early Middle Ages these blank names were adorned with content and in the ninth century the two pairs of saints were the main characters of two very similar hagiographical accounts. The Passion of Helarus and Tatianus resembles a "mirror-text” of the Passio Hermachorae et Fortunati: the narration of the trial before the prefect - with the usual topoi of the genre (tortures, destruction of pagan idols, the power of the Cross, etc.) - and even the vocabulary used by the hagiographer demonstrate that he had at least read the Passion of Hermachora and Fortunatus, but probably had a copy on his desk while writing the Passio Helari et Tatiani. Both the extensive literary borrowings from an old Greek Passion translated into Latin ${ }^{48}$ and the use of the hagiographical text on Hermachora to shape the portrait of Helarus as his mirror-saint, point to the island of Grado, the rival patriarchate under Byzantine control, as the most plausible place of origin for this Passio. ${ }^{49}$ The episcopal church of Grado not only preserved a Greek liturgy, but also had considerable interest in promoting a saint whose relics they possessed. ${ }^{50}$ The treasure of the church of Aquileia had in fact 
been presented as evidence for the rightful claim of the Patriarchate of Grado on the Aquileian metropolitan heritage: Paul the Deacon had recorded in his Historia Langobardorum that the Aquileian patriarch had fled to Grado in 568 carrying with him the entire treasure of his church, a fact later acknowledged also by Maxentius who, nonetheless, underlined that this episode did not mean the transfer of the see and the metropolitan primacy of the Aquileian church to the island of Grado, where the fleeing patriarch had, after all, merely looked for shelter from the barbarian threat. ${ }^{51}$ These few elements clearly reflect the contemporary agenda and strategies undertaken by the Patriarchate of Grado which was pinning its claims on the founding transfer of the metropolitan see of Aquileia to the Byzantine little island in 568: the relics housed in the church treasure then became the symbol of the metropolitan authority relocated in Grado. This is why the possession of these relics was so important to the insular patriarchs. If they could not claim to shelter the relics of Hermachora and Fortunatus, nonetheless they owned the bones of two other martyred bishops of early Christian Aquileia whose legend was every bit as good as theirs. ${ }^{52}$ As a bishop and martyr, Helarus indeed represented the same model of sanctity and could therefore challenge the image and prestige of Hermachora. The competition between the Patriarchates of Cividale and Grado thus also affected the hagiographical literature produced in the two rival episcopal scriptoria. When the Carolingian takeover inspired a renewed confrontation between the two centres, the parallel and competitive shaping of local hagiographical legends was one of the means through which both parties sought to settle the competition in their favour.

In Pavia as well, competitive hagiography is one of the most evident features of the literature written during the early Carolingian period. As I mentioned above, the see 
had been brought under direct authority of Rome around the turn of the seventh century, but was later threatened by several - ultimately unsuccessful - attempts by the Milanese archbishops to pull it back to the traditional subordination. ${ }^{53}$ In the Vita sanctorum Syri atque Iventii (BHL 7976+4619) the hagiographer not only connected the local origins to St Mark and St Peter, but he also fashioned the two holy bishops of Pavia as the first promoters of the cult dedicated to the Milanese martyrs Gervasius, Protasius, Nazarius and Celsus and he even presented them as the first missionaries in pagan Milan. ${ }^{54}$ By doing so, the anonymous author avoided any reference to the role of the metropolitan church of Milan in the organisation of the ecclesia ticinensis, even attempting to reverse the relation and the balance between the two episcopal centres. Saint Syrus anticipated Ambrose in the promotion of the Milanese martyrs: the bishop of Pavia was the first to take special care of them, organising a proper burial and ordering Iventius to place "an epitaph upon which their struggle is written in sacred letters” in the grave of Nazarius and Celsus. ${ }^{55}$ He also wrote a little book recording the deeds and the martyrdom of Gervasius and Protasius, the same libellus that, centuries later, St Ambrose brought to light, unveiling the names and deeds of the hidden saints. ${ }^{56}$ Syrus's successor is then portrayed as the first missionary preaching among the savage pagans (seventes pagani) living in Milan: after performing a miracle, he succeeded in baptising the crowd and proceeded to organise the first Christian local community by ordaining priests and clergy before going back to Pavia. ${ }^{57}$ The Bishopric of Pavia was thus depicted as the senior ecclesia in the history of an emphatically early Christian local past. This is a highly competitive message slipping into the text: the anonymous hagiographer was working hard in defence of the autonomy of the local episcopal church. But this was not all his own work: the hagiographer was certainly drawing upon a pre-Carolingian 
tradition as it is shown by a hymn dedicated to Syrus and Iventius copied directly after the Vita in one of its earliest extant manuscripts (St Gall, Stiftsbibliothek, 566, late ninth- or early tenth-century). ${ }^{58}$ The Ymnus sanctorum Syri et Iventii (BHL 7977b), written on the model of the Ambrosian hymn, provides us with plain evidence of the competition between Pavia and Milan becoming part of hagiography long before the Carolingian takeover: while St Syrus is here briefly remembered as the first preacher and bishop of Pavia, his successor Iventius is described as an active missionary whose major deeds are achieved in Milan where he succeeded in converting and baptising the pagan populace. ${ }^{59}$ Nothing is said about the Roman connection of the local bishops via St Mark and St Peter, and Syrus's portrait is still vaguely drawn. On the basis of this, the Carolingian hagiographer of the Vita sanctorum Syri atque Iventii developed and enhanced the determinant intervention of the local saints in Milan, while he also inserted their legend into the Aquileian one. He was probably writing in the late eighth or early ninth century, at the time of both the affirmation of Milan as the most important Carolingian lieu de mémoire in Italy and the success of the legend of St Mark and St Hermachora sanctioned in Mantua in 827. Pavia's current and preferred status as a see subjected directly to the bishop of Rome thus corresponded to, and was legitimised by, the way the author portrayed the see's supposed origins: Syrus and Iventius had received their mission from St Mark, the well-beloved disciple of the princeps apostolorum Peter, and they were active in Milan long before the latter became a Christian city and a bishopric.

The relation between the episcopal church of Pavia and its metropolitan see had been a matter of contention throughout the Lombard period, but it became even more crucial in the Carolingian age. When Pavia lost its political preeminence, the long 
shadow of the Milanese church and its archbishops became particularly threatening, as Charlemagne showed his preference for the latter in the aftermath of his successful takeover in the Lombard kingdom. It was the Milanese Archbishop, Thomas, who baptised Charlemagne's daughter, Gisela, ${ }^{60}$ and some years later Charlemagne confirmed the foundation and endowment of the monastery named after St Ambrose. In contrast, the Pavese cloisters did not receive any charters before the reign of Lothar I, Charlemagne’s grandson, in Italy in the 820s. ${ }^{61}$ Ambrose was subsequently elevated among the patron saints of the Frankish Kingdom and the monks living in the newlyfounded monastery were expected to pray for the royal family and the integrity and security of the kingdom (stabilitas regni). ${ }^{62}$ The basilica of St Ambrose was also promoted as the royal necropolis of the Carolingian kings of Italy, robbing this honour from the former Lombard capital, Pavia. Pippin of Italy (d. 810) was probably buried in Milan and the dead body of Louis II, Charlemagne’s great-grandson, was brought back here from Brescia by the Milanese archbishop Anspertus in $875 .^{63}$. Throughout the ninth century, the Milanese archbishops thus benefited from a carefully cultivated and widely advertised relation with the Frankish kings. Pavia's attempt to create a prestigious history of its origins can and should be assessed within this context.

A Ambrose, his colleagues and his inventiones: the influence of the Ambrosian model and literature

The hagiographical exploits of Pavia were a response to the completely different hagiographical strategies undertaken in Milan, where Carolingian archbishops relied on Ambrose's great reputation. Their huge investment in this strategy is apparent in many different fields (art, architecture, literature, etc.). The cult of the local doctor ecclesiae, 
presented both as the patron saint of Milan and as a patron saint of the Carolingian Empire alongside St Martin, ${ }^{64}$ was furthermore boosted with the compilation of a second Life (De vita et meritis sancti Ambrosii, BHL 377d) more than four centuries after the first Life, commissioned by St Augustine and written by Ambrose's secretary Paulinus. ${ }^{65}$ Within the hagiographical literature of the Carolingian Kingdom of Italy the Milanese strategies underpinning this new Life represent a striking case. The already extant tradition attaching the foundation of the ecclesia Mediolanensis to Anatelon, one of the disciples of St Peter, was dropped. ${ }^{66}$ This Milanese break with the extant, and potentially profitable, apostolic tradition is the most astonishing example of a sharp change of hagiographical strategy: while the other episcopal churches of Italy further developed, strengthened and promoted the reputation of their local saints in perfect tuning with the pre-Carolingian tradition, in Milan all the attention was suddenly focused on Ambrose alone, while all other local saints who had no connection with him were ignored. $^{67}$

The most distinctive feature of Ambrose as a representative of Carolingian Milan was that he had been the bishop who stood up and challenged the Roman Emperor Theodosius, the prelate who had been praised by St Martin and St Augustine. ${ }^{68}$ The Carolingian predilection for Ambrose soon became evident in the aftermath of Charlemagne takeover in 774, but this attention for the late antique Milanese bishop received an even greater boost when the expanding Frankish Kingdom became an empire. Although the ninth-century hagiographical Milanese text dedicated to Ambrose is difficult to date, the emphasis on the penance imposed on Theodosius as the central episode of his life, and the explicit celebration of the bishop's authority as an imperial adviser, seems to indicate that this compilation was possibly inspired by the 
contemporary public penance of Louis the Pious in $833 .{ }^{69}$ Dating the compilation of the De vita et meritis sancti Ambrosi to the episcopacy of Angilbert II (824-859) becomes particularly tempting for two reasons. First, Angilbert II clearly showed his devotion to St Martin: the patron of the Franks is highlighted both in the Carolingian Life of Ambrose, where the Milanese saint is said to have been taken in dream to Tours where he helped to celebrate St Martin's funeral - an episode borrowed from Gregory of Tours's De virtutibus sancti Martini - and in the iconographical program of the golden

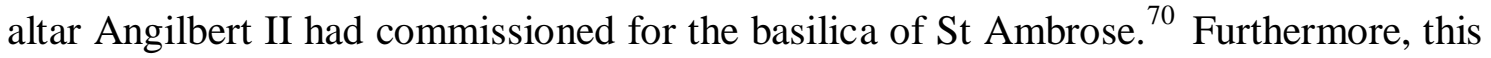
Life's focus on the autonomy and the spiritual supremacy of the bishop accords well with the agenda of Angilbert II as evidenced by the initiatives he undertook both in his ecclesiastical province and in the Kingdom of Italy. ${ }^{71}$ There are also possible echoes of the Synod of Paris (829), which may have served as a source of inspiration for the anonymous hagiographer working in Milan. ${ }^{72}$ Not only is the mediation of the bishop between God and the ruler stressed, but also the importance of increpatio in correcting a misbehaving emperor, and the complementary role of the sacerdos and the imperator. All these are the core elements in both the council acts and the Milanese hagiography, although the latter used late antique literature as a setting for these ideological messages. ${ }^{73}$ This particular version of an ideal imperial bishop, embodied by Ambrose becomes understandable only within the context of more general debates on the government of ecclesia and empire that arose in the 820 and $830 .^{74}$ The close proximity of the Milanese archbishops to Louis II of Italy (844-875) - the first Frankish Emperor who chose Italy as his place of residence - provided many occasions and opportunities to heed the model of Ambrose: it was at the time of the episcopacies of Angilbert II, Tado (860-868) and Anspertus (868-881) that the ecclesia mediolanensis was 
progressively identified as the ecclesia ambrosiana, as it was labeled by Pope John VIII in one of his letters. ${ }^{75}$ The De vita et meritis perfectly fits this political climate.

Of course, for other reasons as well, Ambrose was a powerful and inevitable model of sanctity for Italian hagiographers producing new texts on saints, such as Ambrose's own massive literary legacy. Shaping the portrait of a saint of prestige and fame equal to that of Ambrose could only be achieved by following one of two main paths, competition or emulation. I have already underlined the competitive hagiographical strategies undertaken in Pavia to challenge the authority and prestige of the Milanese church. But strategies of legitimation and persuasion could also entail elevating a local saint to the ranks of St Ambrose's colleagues, a group sharing the same strongly Catholic convictions and a wish to defend these against any heresy, which in late antique Italy mainly was represented by Arianism.

When the bishop of Brescia, Rampertus, decided to commemorate the translation of St Philastrius's relics in a written sermon, he made sure to highlight the qualities of the holy bishop: he was an inflexible preacher against Arianism and he was a colleague of Ambrose whose unflinching activity against this heresy was well-known and documented. ${ }^{76}$ The perfect cooperation between the two holy men is demonstrated by their shared appreciation of the fourth bishop of Bergamo, who was ordained deacon by Philastrius and later consecrated episcopus by Ambrose. ${ }^{77}$

Preaching against the Arian heresy was also an important feature in the profile of the fourth-century St Zeno, the bishop of Verona and author of several sermons in defence of the Catholic faith. His death had been remembered by Ambrose in one of his letters, where he referred to Zeno as a bishop sanctae memoriae whose veneration spread in Verona shortly after his death. ${ }^{78}$ In the late eighth and the early ninth 
centuries the cult of St Zeno was strongly promoted by the ecclesiastical elites of Verona, as shown by the compilation of different texts commemorating the holy local bishop. A poem in praise of the city (Versus de Verona), a sermon and a metric work dedicated to St Zeno (Sermo de vita Zenonis, BHL 9001-9008d; Rythmus de sancto Zenone, BHL 9009) all promoted the holy bishop, enhancing the prestige of the episcopal church and the city of Verona. Together with the monuments of Verona's local past, ${ }^{79}$ St Zeno was one of the glories the local elites could fall back upon in their attempt to promote Verona as the chief town of the kingdom of Italy. ${ }^{80}$

Another cult which claimed Ambrosian antecedents was that of the famous martyrs of Bologna: Vitalis and Agricola. ${ }^{81}$ The details of their exhumation were remembered in one of Ambrose's sermons, the famous Exhortatio Virginitatis (BHL 8689). ${ }^{82}$ It is from this text that the two recensiones of the Passio sanctorum Vitalis et Agricolae (BHL 8690-8691) gleaned the details of their martyrdom. The correspondence in content and text between the Passiones and Ambrose's sermon has often led medieval and modern scholars to attribute the two versions to Ambrose's pen, making them part of the so-called Pseudo-Ambrosian literature. ${ }^{83}$ But the writing of the Passion of Vitalis and Agricola was an entirely Bolognese operation, probably undertaken in the Carolingian period, in order to provide a strong local basis to the memory of these martyrs in competition with the early medieval promotion in Ravenna of the cult dedicated to Gervasius and Protasius, the most famous Ambrosian saints whose hagiography was also a Pseudo-Ambrosian work. Connecting Vitalis and Agricola to Ambrose by means of a hagiographical composition reputed to be the work of the Milanese doctor - and therefore a text of an ancient and very prestigious tradition - was a key element in the strategies of emancipation undertaken by the bishops of 
Bologna. As a consequence of the integration of the Byzantine territories of the exarchate into the regnum langobardorum in the mid-eighth century, ${ }^{84}$ the local episcopal church strove to emancipate itself from the sphere of influence of the archbishops of Ravenna, whose involvement in the political activity of the kingdom was increasing.

In the Carolingian period, recalling the name of Ambrose, be it explicitly or subtly, was one of the strategies undertaken by the anonymous hagiographers to give weight to their claims and their version of the past. 'Emulation' was nothing else than another shade of 'competition': to raise a saint to the level of the most prestigious vir Dei of the pantheon was one of the instruments available for the political and ecclesiastical strategies of Italian bishops as they strove to gain a better position in the hierarchy of the episcopal churches, forced to deal with new kings on the throne and new men in positions of power after 774 .

A

\section{Saints and models of sanctity in hierarchy}

When we compare the hagiographical accounts written in the Carolingian kingdom of Italy to the texts compiled in the same period in other areas of the empire, we are struck by the rather conservative choices made by hagiographers south of the Alps. The Italian authors did not dare go beyond the boundaries of the existing traditions, which restricted them to a limited range of sanctity models. They continued to favour saints whose cults were inaugurated in Late Antiquity and cultivated in the early Middle Ages under the Lombards, on the basis of what they could find in pre-Carolingian sources. This choice was certainly legitimated by the Carolingian predilection for the resources of the past - written texts, traditions, cults -, but it was also made possible by the 
amount of pre-existing and prestigious cultic traditions dating back to the age of the persecutions, and by the availability of a corpus of authoritative late antique literature on these ancient local saints, such as sermons, letters, inscriptions and hymns. The commemoration and the cult of the martyrs had been one of the strategies of early Christians to preserve and celebrate the memory of their heroes and their glorious deaths. By the end of the fourth century, the Christian faith had become the only religion of the empire and such evidence of faith and blood was no longer necessary, or easily attained within the borders of the Roman policy. The birth (nativitas considered as the earthly death and the triumphant entrance in the heavens) of new martyrs became a privilege for Christians venturing outside the Roman Empire or living in troubled areas where doctrinal dissents took violent turns (the African provinces for instance). ${ }^{85}$ Conversely, attaining the nimbus of the saint came to be a prerogative of the viri Dei who stood for the defense and the doctrinal, political, and cultural strengthening of the Christian Church, the so-called sancti confessores. Among them we find many of the Fathers of the Church, but also the local bishops who preached against heresy and acted in protection of the people and the city where they wielded their authority: St Philastrius and St Zeno for instance, are examples of this group.

In manifest adherence to the instructions given at the council of Frankfurt in 794, these two categories of saints - martyrs and confessors - seem to have been the only ones deserving newly-written hagiography in Carolingian Italy. ${ }^{86}$ The hagiographers working in the late eighth and ninth centuries ignored some other models of sanctity: no women or holy abbots were celebrated by new texts. ${ }^{87}$ This clearly does not mean that virgines and abbates were erased from the number of the saints commemorated and venerated in Carolingian Italy, but already existing texts were in 
these cases deemed sufficient to assure their cult and memory. It also shows that nonepiscopal sanctity had less competitive potential. Given that hagiographical production was deeply rooted in episcopal centres, all those saints who were not main characters in the history of bishops tended to fall outside the hagiographers' interests. The focus on the local early Christian saints - preferably martyrs or, even better, martyred bishops and the concentration of hagiographical activity in the episcopal centres, are the main features of hagiography writing in the kingdom of Italy. This stands in sharp contrast with the hagiographical strategies of episcopal and monastic scriptoria north of the Alps: the saints' Lives of the Saxon abbesses and anchoresses, as well as the literature dedicated to the recent missionaries and martyrs to the pagans dwelling beyond the Rhine, show that here different choices were made, both as to new cults promoted and the production of hagiographical texts. The fact that some saints were not born and raised within the walls of the centre promoting their cult did not bother Bavarian or Saxon hagiographers in the least, and the same holds true even for the later period when regional centrifugal forces tore apart Charlemagne's legacy. This is the case, for instance, of St Pusinna's relics: the abbess of Herford, a newly founded Saxon monastery, first obtained Charles the Bald's permission and then transferred, in 860, the precious pignora of a sixth century virgin from Champagne to Saxony, where an anonymous author recorded the miracles performed by the saint during and after the relics translation. ${ }^{88}$ By contrast, the ecclesiastical centres of the kingdom of Italy tended to draw upon local resources with regard to new cults and saints. Here, relic translations took place within the same city - with one exception, the translation of St Mark's holy body from Alexandria of Egypt to Venice in 828, the transfer was nonetheless honoured by a hagiographical account only a century later - while eminent northern Carolingian 
prelates struggled to obtain holy bodies or just little portions of them in Rome, and to assure their safe passage across the Alps to their churches and monasteries.

Yet on both sides of the Alps, martyrs ranked above all the others. This was the most prestigious category of saints, and this fact often compelled Italian hagiographers to justify why their saint had not testified to his faith by martyrdom. An explanation was even needed in the case of the most eminent saint of the Italian pantheon: Ambrose. The anonymous compiler of the De vita et meritis twice insists in his hagiographical work that the bishop merely did not die as a martyr because he was unable to find his executioner, without this in any way being the consequence of any fear of his enemies. $^{89}$

Another feature of the Italian hagiography concerns the manner in which martyrs tended to join up, creating teams. In the episcopal cities of the kingdom of Italy they preached and died in pairs, sometimes as the two main characters of a larger group of viri Dei. ${ }^{90}$ This was a feature of late antique and early medieval legends written when the Roman world (geographically wide and administratively ordered) and the Roman past (chiefly the mass persecutions against Christians unleashed by emperors and prefects) were still fresh memories to be used by hagiographers to build and shape the literary stage for their heroes. ${ }^{91}$ Again, this late antique tradition served as a framework within which Carolingian hagiographers could create new accounts.

Two basic categories, then, were sufficient for any hagiographical need in Carolingian Italy. Although dealing with a very limited and basic range of sanctity models, Italian hagiographers succeeded in shaping and manipulating them to fit the contemporary attempts of the local churches to influence and adjust the political and ecclesiastical balance among the episcopal sees of the Kingdom of Italy. A clear and 
rigid hierarchy of saints in heaven in the hands of anonymous hagiographers became the mirror of the hierarchy of churches they strove to shape on earth.

\section{A Conclusions}

The Carolingian hagiography of the Kingdom of Italy is a very coherent group with a limited range of sanctity models, a preference for the local viri Dei and the local past, against a highly competitive background. All the motives, claims and ambitions conveyed in these accounts have their roots in the local history and the shifting political balance typical of a time of transition. The Frankish court and kings had no place on the Italian hagiographical stage, as the local bishops held all the authority required to manage the sacred, transfer a holy body, or patronise a cult. This is a fundamental contrast with the Carolingian hagiography written north of the Alps, where the royal or imperial approval was deemed necessary to perform a correct translatio. In the kingdom of Italy legitimacy and authority of a local episcopal church were not derived from the royal family and court, but from the local tradition and history. In this context, the centres of production of new or renewed hagiographical accounts were obviously the episcopal scriptoria, with monasteries acting more as the efficient hubs for the distribution of texts. It is certainly a completely different situation from that of contemporary hagiographical production north of the Alps, where the court-connected monasteries represented the chief institutions for the production of new literature and its transmission.

Yet, with all the peculiarities of the Italian hagiographical corpus, it is still possible to place it within the literary horizon of its time. The Carolingian interest in history and the sources of the past, found fertile soil in hagiography: it is precisely the special attention 
paid to the history of local origins and the authority of late antique texts that places Italian hagiography in the wider context of Carolingian literature. The texts produced in a periphery of the realm, and mainly for local purposes, thus shared the most distinctive features of correctio, the cultural movement that was meant to ensure the successful integration of the Roman and Christian empire reborn under Charlemagne. 
${ }^{1}$ For a good synthesis over the political uses of relics in the Middle Ages see E. Bozóky, La politique des reliques de Constantin à Saint Louis. Protection collective et légitimation du pouvoir (Paris, 2006).

2 The Carolingian interest in the management and transfer of relics has been underlined in P. Geary, 'The Ninth-Century Relic Trade. (A response to Popular Piety?)', in J. Obelkevich (ed.), Religion and the People, 800-1700 (Chapel Hill, NC, 1979), pp. 8-19. For a case study on the use of hagiographical literature for political claims see G. Vocino, 'Hagiography as an instrument for political claims in Carolingian northern Italy: the Saint Syrus dossier (BHL 7976 and 7978)', in P. Sarris, P. Booth and M. Dal Santo (eds.), An Age of Saints? Power, Conflict and Dissent in Early Medieval Christianity, Brill’s Series on the Early Middle Ages 20 (Leiden, 2011) pp. 169-186.

${ }^{3}$ For an overview over the Carolingian tastes in hagiography see P. Fouracre, 'The origins of the Carolingian attempt to regulate the cult of saints', in P. Hayward and J. Howard-Johnston (eds.), The Cult of Saints in Late Antiquity and the Middle Ages: Essays on the Contribution of Peter Brown (Oxford, 1999), pp. 143-165; K. Heene, 'Merovingian and Carolingian hagiography: continuity or change in public and aims?', Analecta Bollandiana 107 (1989) pp. 415-428; P. Riché, 'Les Carolingiens en quête de sainteté', in Les fonctions des saints dans le monde occidental (IIIe-XIIIe siècle). Actes du colloque organisé par l'École Française de Rome avec le concours de l'Université de Rome «La Sapienza », Roma 27-29 octobre 1988, Collection de l’École Française de Rome 149 (Rome, 1991), pp. 217-224; A.K. Bosworth, 'Learning from the Saints : 
Ninth-Century Hagiography and the Carolingian Renaissance', History Compass 8/9 (2010), pp. 1055-1066.

4 For an in-depth analysis of the Carolingian use of the written word see $\mathrm{R}$. McKitterick, The Carolingians and the Written Word (Cambridge, 1989). The uses of the past and ancient traditions in the Carolingian world have been analysed in many articles gathered in Y. Hen and M. Innes (eds.), The uses of the Past in the Early Middle Ages (Cambridge, 2000) as well as in R. McKitterick, Perceptions of the Past in the Early Middle Ages (Notre Dame, IN, 2006). A recent volume dedicated to the memory of Rome across medieval Europe also gathers some interesting contributions on this aspect, see C. Bolgia, R. McKitterick and J. Osborne (eds.), Rome across Time and Space. Cultural Transmission and the Exchange of Ideas, c. 500-1400 (Cambridge, 2011).

${ }^{5}$ I just mention here the recent exhaustive synthesis by Steffen Patzold where a detailed bibliography can also be found, see S. Patzold, Episcopus. Wissen über Bischöfe im Frankreich des späten 8. bis frühen 10. Jahrhunderts, Mittelalter-Forschungen 25 (Ostfildern, 2008).

${ }^{6}$ The bibliography on this specific theme is far too copious to provide a complete overview. For further reading on the strong bond between Italian bishops and cities from Late Antiquity to the Middle Ages, I signal the recent book by M. Pellegrini, Vescovo e città. Una relazione nel Medioevo italiano (secoli II-XIV) (Milan, 2009). Episcopal authority in relation to the material, demographic and social transformations 
of the late antique and early medieval city has also received in-depth attention, thanks to the new data provided by archeological surveys; see for instance M.C. Miller, The Bishop's palace. Architecture and authority in medieval Italy (Ithaca, 2000). Furthermore, the role of churches as foci of identification- in urban as well as rural contexts - is now at the heart of important research projects such as the one sponsored by the University of Padua on "Urban identities in north-eastern Italy $\left(9^{\text {th }}-11^{\text {th }}\right.$ century). This project runs parallel to the ERC Advanced Grant "Social Cohesion, Identity and Religion in Europe” (SCIRE, 2011-2016) awarded to the University of Vienna and the Austrian Academy for Social Sciences; its panel "Small worlds - wide horizons: local identities and social cohesion (700-1050) especially deals with the role of ecclesiastical authorities in the complicated process of formation of local identities.

${ }^{7}$ For an excellent case study on the strategies of power undertaken by the local elites of the Middle Rhine Valley see M. Innes, State and Society in the early Middle Ages. The Middle Rhine Valley, 400-1000 (Cambridge, 2000).

${ }^{8}$ The main reference on the rise of the cult of saints still is P. Brown, The Cult of the Saints. Its Rise and Function in Latin Christianity (Chicago, IL, 1981).

${ }^{9}$ For a comprehensive presentation of the earliest passionarii and an accurate analysis of the successful process of affirmation of these hagiographical collections see $\mathrm{F}$. Dolbeau, 'Naissance des homéliaires et des passionnaires. Une tentative d'étude comparative', in S. Gioanni and B. Grévin (eds.), L'antiquité tardive dans les 
collections médiévales : textes et représentations, VIe-XIVe siècle, Collection de l’École Française de Rome, 405 (Roma, 2008), pp. 13-35, esp. pp. 26-35.

10 The use of the term correctio instead of Renaissance or reform is now preferred by scholars pointing out that this was the word used in the sources and this was how they conceived their intervention on ecclesiastical matters as well as on cultural knowledge and power, see R. McKitterick, Charlemagne. The formation of a European Identity (Cambridge, 2008), pp. 292-380.

11 Sinodus Franconofurtensis (a. 794), ed. A. Boretius, MGH Capitularia I (Hanover, 1883), no. 28, p. 77: 'ut nulli novi sancti colantur aut invocentur, nec memoria eorum per vias erigantur; sed hii soli in ecclesia venerandi sint qui ex auctoritate passionum aut vitae merito erecti sint.' English translation by P.D. King, Charlemagne. Translated Sources (Kendal, 1987), p. 229.

In a letter addressed by Pope Hadrian I to Charlemagne in 791 we read that 'the Lives of the Fathers which aren't written by proved authors shall by no means be read in the church. But those written by accredited orthodox authors shall be accepted and read ('Vitas enim patrum sine probabilibus auctoribus minime in ecclesia leguntur. Nam ab orthodoxis titulatas et suscipiuntur et leguntur.' Epistolae selectae Pontificum Romanorum, 2, ed. K. Hampe, MGH Epistolae Karolini Aevi, III, p. 49).

12 The Carolingian adbreviationes (BHL 2837 and 2838) of the epic Passio sanctorum Faustini et Iovitae (BHL 2836) omit the episode dedicated to an onager addressing the crowd and drawing it to conversion. Paolo Tomea has clearly shown that speaking 
animals were one of the characteristic features of apocryphal late-antique literature this particular episode featuring an onager can also be found in the Syriac and Greek Acts of the apostle Thomas (cf. M. Geerard, Clavis apocryphorum Novi Testamenti (Turnhout, 1992), no. 245.I and 245.II) written in Edessa during the third century - but they were later regarded as possible source of heretical deviation, cf. P. Tomea, 'Agni sicut nive candidi. Per un riesame della Passio Faustini et Iovite BHL 2836', in G. Archetti and A. Baronio (eds.), San Faustino Maggiore di Brescia. Il monastero della città, Brixia Sacra. Memorie Storiche della Diocesi di Brescia, 3rd ser, 11 (Brescia, 2006), pp. 17-48, esp. pp. 34-46.

13 This same aspect has been highlighted by Rosamond McKitterick in her book on Charlemagne showing how the Carolingian policy was well integrated and perfectly working without the necessity of the king's presence, cf. R. McKitterick, Charlemagne, pp. 214-291.

${ }^{14}$ It is now widely accepted that Lives and Passions of saints probably circulated at the very beginning of their transmission as libelli and only in a second moment they were integrated in a Passionarius or in a heterogeneous collection of texts, see J.-C. Poulin, 'Les libelli dans l'édition hagiographique avant le XIIe siècle', in M. Heinzelmann (ed.), Livrets, Collections and Textes. Études sur la tradition hagiographique latine, Beihefte der Francia 63 (Ostfildern, 2006), pp. 15-193.

15 The number in the most complete hagiographical repertory, the Bibliotheca Hagiographica Latina, shall always be indicated to identify each text and its different 
recensions, cf. Bibliotheca Hagiographica Latina, ed. Société des Bollandistes (Brussels, 1898-9).

16 A digital reproduction of the manuscript is available online on http://www.ecodices.unifr.ch.

17 Aquileia, the Roman city at the head of the Adriatic on the edge of the lagoons, was one of the metropolitan sees charged, with Milan and Ravenna, with the ecclesiastical government of northern Italy.

18 The Passionarius of Reichenau (Karlsruhe, Badische Landesbibliothek, Augiensis XXXII) and the one from Sankt Lambrecht (Graz, Universitätsbibliothek, 412) are both dated back to the $9^{\text {th }}$ century. The modern editor of the Passio Hermachorae et Fortunati (BHL 3838) has convincingly argued that the codex Augiensis XXXII, bearing a libellus gathering a small corpus of Aquileian hagiographies, is probably the result of the transcription of a small passionarius from Italy or a selective choice of texts taken from a larger collection of Italian hagiographies compiled in the territories of the former regnum langobardorum cf. P. Chiesa, 'I manoscritti delle Passiones aquileiesi e istriane', in E. Colombi (ed.), Le Passioni dei martiri aquileiesi e istriani (Roma, 2008), esp. p. 109.

19 As Michel Sot underlined, hagiographical accounts also served as property back up documents: the bishops of Le Mans used in several occasion its Gesta episcoporum to protect its territorial rights, see M. Sot, 'Historiographie épiscopale et modele familial 
en Occident au IXe siècle’, Annales. Économies, Sociétés, Civilisations 33/1 (1978), pp. 433-449, esp. pp. 442-445.

${ }^{20}$ The competition between the episcopal sees of Cividale and Grado, both claiming to be the legitimate heirs of the Patriarchate of Aquileia, was one of the results of the schism that had occurred in the sixth century as a consequence of the so-called Three Chapters controversy. In 610, after the election of the dissident Patriarch John, an internal opposing faction backed by the Byzantines proceeded to consecrate Candidianus, who pleaded his loyalty to the Three Chapters. Thenceforth the filobyzantine patriarchs lived in Grado under Byzantine control while their dissident rivals moved into the Lombard Kingdom and chose Cividale, chief town of the Duchy of Friuli, as their place of residence. On the Three Chapter schism see C. Chazelle and C. Cubitt, The Crisis of the oikumene. The Three Chapter and the Failed Quest for Unity in the Sixth-Century Mediterranean, Studies in the Early Middle Ages 14 (Turnhout, 2007). On the consequences of the Three Chapter controversy in Italy, see C. Sotinel, The Three Chapters and the Transformations of Italy, in C. Chazelle and C. Cubitt, The Crisis of the oikumene, pp. 85-120, esp. pp. 109-120. In the same volume also see C. Azzara, Il regno longobardo in Italia e i Tre Capitoli, ibidem, pp. 208-222. On the origins of the competition between Aquileia and Grado see P. Cammarosano, 'Aquileia e Grado nell'Alto Medioevo', in M. Mirabella Roberti (ed.), Aquileia e l'Alto Adriatico, Antichità Altoadriatiche 36 (Udine, 1990) pp. 129-155.

${ }^{21}$ The Acts of the council of Mantua (hereafter Concilium Mantuanum) are edited by A. Werminghoff, MGH Concilia Aevi Karolini II, pp. 583-589. 
${ }^{22}$ Concilium Mantuanum, p. 587.

23 Ibidem, p. 585: 'Residentibus igitur in hac synodo reverentissimis episcopis, adstantibus diaconibus et caetero clero, veniens vir sanctissimus Maxentius, Aquileiensis patriarcha, precum libellos pro dispersione suae Aquileiensis aecclesiae obtulit, ut suae provintiae ecclesias, quas Barbarorum incursus a sua matrice segregaverat, auctoritate canonum iam pacis tempore percipere mereretur ad propria: «Nos, qui veritate perfecta invenimus a beato evangelista Marco, qui spiritualis et ex sacro fontis utero ac carissimus sancti Petri apostoli fuit filius, necnon ab elegantissimo Hermachora, Aquileiensem aecclesiam pre omnibus Italiae in Christi fide fundatam esse et pastoralem ibi semper curam servatam et sanctorum apostolorum sanctae Romanae aecclesiae doctrinis imbutam atque ipsam semper eius fuisse discipulam et peculiarem ac vicariam in omnibus. Quemadmodum insertum in eiusdem Aquileiensis aecclesiae comperimus sacris litteris».'

${ }^{24}$ On the council of Mantua and the coincidence of vocabulary with the Passion of Hermachora and Fortunatus see G. Vocino, Santi e luoghi santi al servizio della politica carolingia (774-877). Vitae e Passiones del Regno Italico nel contesto europeo, $\mathrm{PhD}$ thesis, University “Cà Foscari” of Venice (2010), pp. 179-183 (available online http://dspace.unive.it/handle/10579/958).

${ }^{25}$ Concilium Mantuanum, p. 588. 
${ }^{26}$ On the enormous flow of relics from Rome to Francia during the Carolingian period see J.M.H. Smith, 'Old saints, New Cults: Roman relics in Carolingian Francia', in eadem (ed.), Early Medieval Rome and the Christian West (Leiden, 2000), pp. 317-339.

${ }^{27}$ For an excellent complete study on episcopal memory in early medieval northern Italy see J. Ch. Picard, Le souvenir des évêques. Sépultures, listes épiscopales et culte des évêques en Italie du Nord des origines au $X^{e}$ siècle, Bibliothèque des Écoles françaises d'Athènes et de Rome 268 (Roma, 1988).

${ }^{28}$ The Frankish Milanese Archbishop Angilbert II (824-859) made great use of relics to tighten and strengthen the bonds with the bishoprics and monasteries under his metropolitan jurisdiction, see P. Tomea, 'Nunc in monasterio prefato Clavadis nostro tempore conditus requiescit. Il trasferimento di Calocero a Civate e altre traslazioni di santi nella provincia ecclesiastica di Milano e nei suoi dintorni tra VIII e X secolo’, in C. Bertelli (ed.), Età Romanica. Metropoli, contado, ordini monastici nell'attuale provincia di Lecco (XI-XII secolo). Atti del convegno 6-7 giugno 2003, Varenna - Villa Monastero (Milano, 2006), pp. 159-189.

${ }^{29}$ Hilduin of St Denis made perfectly clear which was the correct sequence to perform a translatio when he advised the praepositus of Saint-Médard of Soissons, who was longing for Roman relics, to ask for imperial permission before undertaking his travel to Rome (Odilo, Ex translatione sancti Sebastiani, ed. O. Holder Egger, MGH SS XV/I, p. 381). For further details on the ways translations were performed north of the Alps see G. Vocino, 'Le traslazioni di reliquie in età carolingia (fine VIII-IX secolo): uno studio 
comparativo', in Rivista di Storia e Letteratura Religiosa 44 (2008), 2, pp. 207-255, esp. pp. 220-223.

30 The Carolingian legislation had hardly tried to regulate the cults of saints imposing the previous approval of any relics translation given by the king or the episcopal council. See the acts of the council held in Mainz (813), Concilium Moguntinense, ed. A. Werminghoff, MGH Concilia Aevi Carolini I, ch. 51, p. 272.

31 Translatio sancti Filastrii (BHL 6797), ch. 1, ed. M. Bettelli Bergamaschi, 'Ramperto vescovo di Brescia (sec. IX) e la Historia de Translatione beati Philastrii', Ricerche Storiche sulla Chiesa Ambrosiana 5 (1975), p. 126: 'Speramus enim sanctorum meritis nos omnium foveri et maxime eorum quorum amplectimur corpora quorumque vel nativitas vel habitatio fuit con patribus nostris. Eorum quippe vel dogmate instruimur, vel exemplo martyrii corroboremur.' On the promotion of the cult of St Philastrius in the ninth century see G. Vocino, Triginta autem Brixienses sunt episcopi quos meminimus. Mémoire épiscopale et hagiographie à l'époque carolingienne: le dossier de saint Filastre évêque de Brescia, in M. Coumert, M.-C. Isaïa, K. Krönert and S. Shimahara (eds.), Rerum gestarum scriptor. Histoire et historiographie au Moyen Âge (Paris, 2012), pp. 313-328.

${ }^{32}$ For a complete study of the foreigners who made their careers in the Italian Kingdom see E. Hlawitschka, Franken, Alemannen, Bayern und Burgunder in Oberitalien (774962) (Freiburg im Breisgau, 1960). 
${ }^{33}$ The earliest occurrence of this definition is to be found in the epistles of pope John VIII (872-882), see Registrum Iohannis VIII, ed. E. Caspar, MGH Epistolae VII, p. 269.

${ }^{34}$ On the tensions between Ratold and the local elites in the aftermath of the rebellion of Bernard of Italy (818) and later during the opposition of Lothar I to his father Louis the Pious, see G. Tondini, 'Un modello per il regno dei Carolingi in Italia. L’Epitome Phillipsiana e l'identità urbana di Verona dopo il 774', Ph.D. thesis, University of Padua (2011), esp. pp. 393-433.

35 A peculiar source of the Lombard and then Carolingian Italian Kingdom are the socalled Laudes Civitatum celebrating the city, its history and glories. On these sources see G. Fasoli, 'La coscienza civica nelle Laudes Civitatum', in La coscienza civica nei comuni italiani del Duecento, Convegni del Centro di Studi sulla Spiritualità medievale. Università degli Studi di Perugia 11 (Todi, 1972), pp. 11-44 ; J.Ch. Picard, 'Conscience urbaine et culte des saints de Milan sous Liutprand à Vérone sous Pépin I ${ }^{\mathrm{er}}$ d’Italie', in Hagiographies, Cultures et Sociétés (IVème-XIIème siècles). Actes du colloque organisé à Nanterre et à Paris (2-5 Mai 1979) (Paris, 1981), pp. 455-469; T. Granier, 'La renovatio du modèle rhétorique antique dans les éloges urbains de l’Italie du haut Moyen Âge', in M. Balard and M. Sot (eds.), Au Moyen Âge, entre tradition antique et innovation, Comité des Travaux Historiques et Scientifiques, Histoire, 36 (Paris, 2009), pp. 35-56.

${ }^{36}$ Attention to the uses of the past in the early Middle Ages has been drawn by the publications already mentioned at note 4 . This perspective is now at the heart of the 
interests of the current research project "Cultural memory and the resources of the past (400-1000 AD)" undertaken by an international team of scholars from the University of Vienna, Utrecht, Leeds and Cambridge (webpage http://cmrp.oeaw.ac.at/project.htm).

${ }^{37}$ Late antique sources did not give details about St Mark stay in Italy. Eusebius of Caesaria’s Historia ecclesiastica, translated into Latin by Rufinus of Aquileia in the late fourth century, merely recorded the mission of St Mark to Rome where he wrote his Gospel on the demand of the local new Christians before heading to Alexandria of Egypt (cf. Eusebius-Rufinus, Historia ecclesiastica, ed. T. Mommsen, Eusebius Werke, I (Leipzig, 1903), book II, chs. 15-16, p. 141).

${ }^{38}$ On the Liber de episcopis Mettensibus by Paul the Deacon see M. Sot, 'Le Liber de episcopis Mettensibus dans l'histoire du genre Gesta episcoporum', in P. Chiesa (ed.), Paolo Diacono. Uno scrittore tra tradizione longobarda e rinnovamento carolingio (Udine, 2000), pp. 527-549. On the Gesta episcoporum as a literary genre see M. Sot, Gesta episcoporum, Gesta abbatum, Typologies des sources du Moyen Âge Occidental 37 (Turnhout, 1981).

${ }^{39}$ Paul the Deacon, Liber de episcopis Mettensibus, ed. G. H. Pertz, MGH SS II, p. 261: 'igitur cum Romam pervenisset (i.e. Peter), illico qui summas quasque urbes in occiduo positas Christo domino per verbum fidei subiugaret, optimos eruditosque viros ex suo consortio direxit. Tunc denique Apollinarem Ravennam, Leucium Brundisium, Anatolium Mediolanum misit. Marcum vero, qui praecipuus inter eius discipulos 
habebatur, Aquilegiam destinavit, quibus cum Hermagoram, suum comitem, Marcus praefecisset, ad beatum Petrum reversus, ab eo nihilominus, Alexandriam missus est.'

40 This dispatch is reported for the first time by the tenth-century Translatio sancti Marci (BHL 5283-5284) recording the transfer of the holy body of the evangelist Mark from Alexandria of Egypt to Venice, see Translatio Marci evangelistae Venetias, ed. E. Colombi, 'Translatio Marci evangelistae Venetias (BHL 5283-5284)', Hagiographica 17 (2010), pp. 73-129. In the Translatio, the Venitian anonymous hagiographer states: 'in quo etiam loco (i.e. Grado) post paucum tempus Helias egregius patriarcha, [...], ex consensu beatissimi papae Pelagii, facta synodo viginti episcoporum, eandem Gradensem urbem totius Venetiae metropolim esse instituit. Ad cuius roborem Heraclius post haec augustus beatissimi Marci sedem, quam dudum Helena Constantini mater de Alexandria tulerat, sanctorum fultus amore direxit, ubi et hactenus veneratur pariter cum cathedra in qua beatus martyr sederat Hermachoras’ (ibidem, pp. 115-116).

41 This tradition shows just some minor variations concerning the appointment of Hermachora by St Mark, as it was first stated by Paul the Deacon in his Liber de episcopis Mettensibus, or St Peter, as testified by the Passio sanctorum Hermachorae et Fortunati (BHL 3838) probably written in Cividale, the chief town of the Lombard duchy of Friuli.

${ }^{42}$ Vita sanctorum Syri atque Iventii (BHL 7976+4619), ed. N. Everett, 'The earliest recension of the Life of S. Sirus of Pavia (Vat. Lat. 5771)', Studi Medievali 43 (2002), p. 922: 'Beatum vero Armagoram quem ipse (i.e. Marcus) edocavit et enutriit ordine 
vicis suae Italiae prudentia et sanctitate reliquit insignem. Huius auditores atque ministri venerabiles viri fuerunt Syrus atque Iventius. Ecce enim a fonte luminis inestimabilis claritas procedens per beata pectora derivata Ticinensis populi animas circumfulsit ita. A Christo in Petrum, a Petro in Marcum, a Marco vero in Armagoram, ab Armagora in beatissimos viros Syrum atque Iventium transcurrit.[...] Convocans (i.e. Armagoras) alumnum suum Syrum episcopali fastigio dedicavit atque consocians illi beatum Iventium ad evangelizandum nomen domini nostri Iehsu Christi Papiam direxit.' The English translation is also published by Nick Everett in the article above, p. 944.

${ }^{43}$ On the competition between Pavia and Milan in the Middle Ages see P. Majocchi, Pavia città regia. Storia e memoria di una capitale altomedievale (Roma, 2008). On the early Middle Ages see especially pp. 17-67.

${ }^{44}$ Entering the city of Pavia, Syrus boasted in a double-edged prophecy (praesagium): the announcement of future wealth and fame for the small town of Pavia and the pitiless misfortune of Aquileia to be destructed by impious hands (impiorum manus) and never to be rebuilt ('Rejoice city of Pavia, for fame will come to you from the eternal mountains, and no longer will you be called smallest, but rather the richest among neighbouring cities. But woe on you Aquileia, for you will fall into the hands of the wicked and be destroyed. You shall never be rebuilt to rise again‘, transl. by N. Everett, 'The earliest recension', p. 861). The missionary activities of Syrus and Iventius in Milan, Verona, Brescia and Lodi made them a pair of successful Italian evangelizers who preached, baptized and organized the first Christian communities of northern Italy 
(on the relations between the Italian towns displayed in the Life of saint Syrus see N. Everett, 'The earliest recension', pp. 860-872).

45 The mentioned passionnarius of Reichenau (Augiensis XXXII).

${ }^{46}$ For the edition of this Passio, an enlightening introduction and the Italian translation of the text see M. Cerno, 'Passio Helari et Tatiani', in E. Colombi (ed.), Le Passioni dei martiri aquileiesi, pp. 277-326.

47 Martyrologium Hieronymianum, ed. H. Quentin, AASS Nov. II, Pars Posterior (Bruxelles, 1931), p. 371: 'In Aquileia sanctorum Fortunati et Armageri.' Ibidem, pp. 147-148: (XVII Kal. April.) 'In Aquileia Hilari Tasiani Datiani’; (XVI Kal. April.) 'In Aquileia ad Porto Largi Hilari Titiani.’

${ }^{48}$ On the literary borrowings from the Greek and Latin Passion of St Ananias (BHG 2023, BHL 397) see M. Cerno, 'Un modello letterario dell'agiografia aquileiese: Anania (BHL 397)', Vetera Christianorum 44 (2007) pp. 13-32.

49 For a detailed presentation of the literary borrowings and the hagiographical models reused by the hagiographer of Helarus and Tatianus see G. Vocino, Santi e luoghi santi, pp. 173-179 and 183-189. 
$\overline{50}$ The Patriarchate of Grado probably owned hagiographical collections and accounts dedicated to Greek saints and it's even possible that some of these texts were translated into Latin in the local scriptorium.

51 Paul the Deacon, Historia Langobardorum, ed. L. Capo, Storia dei Longobardi (Milan, 1992), p. 88: 'quoque civitati eiusque populis beatus Paulus patriarcha praeerat. Qui Langobardorum barbariem metuens, ex Aquileia ad Gradus insulam confugiit secumque omnem suae thesaurum ecclesiae deportavit.' Cf. Concilium Mantuanum, p. 585: 'ex civitate Aquileiensi et de propria sede ad Gradus insulam, plebem suam, confugiens (i.e. Patriarch Paul) omnemque thesaurum et sedes sanctorum Marci et Hermachorae secum ad eamdem insulam detulit idcirco, non ut sedem aut primatum aecclesiae suaeque provintiae construeret inibi, sed ut Barbarorum rabiem possit evadere.'

${ }^{52}$ In the Chronicle on the singular Patriarchs of the new Aquileia, a text written in Grado in the early eleventh century during a period of strong renewed competition between the two rival patriarchates, the names of Helarus and Tatianus are openly listed when mentioning the relics transferred from Aquileia to Grado in 568. See Chronica de singulis patriarchis Novae Aquileiae, ed. L. A. Berto, p. 154: 'Paulus, [...] Longobardis advenientibus, cum omni thesauro ecclesiae Gradus se contulerat, afferens secum corpora sanctorum martyrum Hilari et Taciani et reliquorum.’

53 Cf. Liber Pontificalis, ed. L. Duchesne, I, (Paris, 1886), pp. 391-392. 
$\overline{54}$ The inventio of the Milanese martyrs had been recorded both in Ambrose's sermons and in the early Life of Ambrose by his secretary Paulinus, see Epistula LXXVII (22), ed. M. Zelzer, Sancti Ambrosi Opera. Pars X, Corpus Scriptorum Ecclesiasticorum Latinorum, 82/III (Vienna, 1982), pp. 126-140; Vita Ambrosii, ed. A.A.R. Bastiansen, Vita di Cipriano, Vita di Ambrogio, Vita di Agostino (Milano, 1981), ch. 14 and chs. 3233, pp. 70-72 and 94-96.

55 Vita sanctorum Syri atque Iventii (BHL 7976+4619), ed. N. Everett, p. 926: 'epitaphium certaminis eorum sacris apicibus conscribentes.'

56 N. Everett, 'The earliest translation', pp. 926-7. This detail is reported in the renowned late-antique pseudo-Ambrosian letter also known as the Passio sanctorum Gervasii et Protasii (BHL 3514), see PL XVII, cols. 742-747, esp. col. 744A: ‘cumque ab eo eorum nomina requirerem, dixit mihi: Ad caput eorum libellum scriptum invenies, in quo et ortus eorum, et finis scriptus est.'

${ }^{57}$ Vita sanctorum Syri atque Iventii, ed. N. Everett, p. 955.

58 An analysis and the edition of the Ymnus sanctorum Syri et Iventii (BHL 7977b) is provided in G. Vocino, Santi e luoghi santi, pp. 122-128 and 367-369.

59 Four out of the thirteen stanzas of the hymn are dedicated to the Milanese mission of Iventius, making it clear that this was indeed the central episode of the two saints' Lives. 
${ }^{60}$ ARF, ed. G.H. Pertz, MGH SRG in usum scholarum, a. 781, p. 56.

${ }^{61}$ The royal confirmation charter given to Sant'Ambrogio is edited by E. Mühlbacher, MGH Diplomatum Karolinorum I (Hannover, 1906), no. 164, pp. 221-222. On the absence of charters and the socalled 'Pavese punishment' see A.A. Settia, 'Pavia carolingia e postcarolingia’, in Storia di Pavia, 4 vols. (Pavia, 1984-95), II, pp.74-75.

${ }^{62}$ MGH Diplomatum Karolinorum, I, no. 164, p. 222: 'pro nobis uxorique nostre ac liberis seu stabilitatem regni nostri domini misericordiam iugiter exorare.’

63 The claim of Louis II's body by the Milanese archbishop Anspertus is related by Andreas of Bergamo in his continuation of the Historia Langobardorum by Paul the Deacon, see Andreas of Bergamo, Historia, ed. G. Waitz, MGH Scriptores Rerum Langobardicarum et Italicarum (Hanover, 1878), p. 229.

${ }^{64}$ The iconographic program dedicated to Ambrose by the archbishop Angilbertus II (824-859) presented the Milanese saint as the Italian counterpart of St Martin, the late antique holy bishop of Gaul and the patron saint of the Franks. On the magnificent Carolingian golden altar depicting the Life of Ambrose see the articles gathered in C. Capponi (ed.), L'altare d'oro di Sant'Ambrogio (Milan, 1996) as well as C. Hahn, 'Narrative on the Golden Altar of Sant'Ambrogio in Milan: Presentation and Reception’, Dumbarton Oaks Papers 53 (1999), pp. 167-187. 
$\overline{65}$ The Carolingian Life of Ambrose is a twentieth century discovery. The only existing manuscript is a $9^{\text {th }}$ century copy now conserved in St Gall (Stiftsbibliothek 569). For the edition of the text with an exhaustive introduction and the analysis of the many literary borrowings see De Vita et Meritis sancti Ambrosii, ed. P. Courcelle, Recherches sur saint Ambroise. "Vies” anciennes, culture, iconographie (Paris, 1973), pp. 49-121. For a more recent - and extremely accurate - study of the Milanese hagiographical production dedicated to Ambrose and his siblings see P. Tomea, 'Ambrogio e i suoi fratelli. Note di agiografia milanese medievale', Filologia mediolatina 5 (1998), pp. 149-232.

${ }^{66}$ This tradition - attested by Paul the Deacon in his Liber de Episcopis Mettensibus (cf. note 37) - surfaced again to find its definitive shape only in the late tenth century when a coherent and strong local apostolic tradition was pinned on Barnabas, the famous companion of St Paul. It is worth noting that Milan will no longer be presented as a Petrine foundation: a parallel and independent genealogical line will be build to draw a history of the origins challenging the most prestigious foundations, even Rome. The Milanese apostolic tradition is the focus of a brilliant in-depth study by the Italian scholar P. Tomea, Tradizione apostolica e coscienza cittadina a Milano nel Medioevo. La leggenda di San Barnaba, Bibliotheca Erudita. Studi e documenti di Storia e Filologia, 2 (Milano, 1993).

${ }^{67}$ In the Carolingian period ( $8^{\text {th }}-10^{\text {th }}$ century) also the lay brother of Ambrose, Satyrus, and his sister Marcellina were made the main character of two new hagiographical accounts: the Vita Satyri (BHL 7510) predates the compilation of the De vita et meritis, 
while the Vita Marcellina (BHL 5223) is a later work. On these hagiographical accounts see again P. Tomea, 'Ambrogio e i suoi fratelli'.

68 The Carolingian learned men showed a renewed interest in Ambrose and the renowned episode of Theodosius' penance was presented as the example of the ideal relation and collaboration between a king and his bishops, see P. Tomea, 'Ambrosio e i suoi fratelli', pp. 181-183. The "world of Ambrose" is also the frame wherein Paschasius Radbert set his apology of Wala, see M. de Jong, 'Becoming Jeremiah: Paschasius Radbertus on Wala, himself and others', in R. Corradini, M. Gillis, R. McKitterich and I. van Renswoude (eds.), Ego trouble. Authors and their Identities in the Early Middle Ages (Vienna 2010), pp. 185-196.

${ }^{69}$ On the role of the bishops bending Louis the Pious to make public amends of his sins see M. de Jong, The Penitential State. Authority and Atonement in the Age of Louis the Pious 814-840 (Cambridge, 2009).

${ }^{70}$ Cf. De vita et meritis, pp. 106-107 and C. Hahn, 'Narrative on the Golden Altar', pp. 174-176.

${ }^{71}$ P. Tomea, ‘Ambrogio e i suoi fratelli', pp. 183-185.

72 For the acts of the council of Paris see Concilium Parisiense (829), ed. A. Werminghoff, MGH Concilia Aevi Karolini II (Hannover/Leipzig, 1908), pp. 605-680. This fundamental document has been analysed and contextualized in the overall 
programme of reform undertaken in the late 820 s by the Carolingian episcopate by $\mathrm{M}$. de Jong, The Penitential State, pp. 176-184. On the council of Paris 829 see also S. Patzold, Episcopus, pp. 149-160.

73 Particularly interesting is the following passage borrowed from the Historia Tripartita where Theodosius explains how helpful can be an increpatio pronounced by a virtuous man. De Vita et meritis sancti Ambrosii, ed. P. Courcelle, p. 91: “ «Vix,» inquid (i.e. Theodosius), «potui discere, quae differentia sit imperatoris et sacerdotis; vix enim veritatis inveni magistrum. Ambrosium namque solum novi vocari digne pontificem. Tantum itaque prodest increpatio a viro virtutibus florente prolata».'

${ }^{74}$ On the progressive definition of the role and place of the ecclesia in the early medieval polity, and particularly the Carolingian Empire, see M. de Jong, 'The State of the Church: ecclesia and early medieval state formation', in: W. Pohl and V. Wieser (eds.) Der frühmittelalterliche Staat: Europäische Perspektive Forschungen zur Geschichte des Mittelalters 16 (Vienna, 2009) 241-255.

${ }^{75}$ Cf. n.33.

${ }^{76}$ Translatio sancti Filastrii (BHL 6797), ed. M. Bettelli Bergamaschi, p. 135: ‘Qualem eum in Arrianorum nefandae procellae temporibus sanctissimae memoriae Ambrosius Mediolanensis episcopus esse intellexit, qui sibi eum collegam habebat?' 
$\overline{77}$ Ibidem, p. 135: 'quantique meriti vicini episcopi eundem esse existimabant, si quartus Pergamensis episcopus in epitaphio tertii episcopi, hoc est praedecessoris sui, ni fallor, meminisse studuit, quod Ambrosius ipsum episcopum et Filastrius consecravit diaconum?’

${ }^{78}$ Ambrose of Milan, Epistula LVI (Maur. 5), ed. M. Zelzer, Sancti Ambrosii Opera. Pars X: Epistulae et Acta, II, Epistularum Libri VII-IX, Corpus Scriptorum Ecclesiasticorum Latinorum 82/2 (Vienna, 1990), p. 84. The famous miracle performed on the waters of the Adige, the river surrounding the city of Verona, is recorded no less than by Gregory the Great in his Dialogues (cf. Gregory the Great, Dialogi libri IV, ed. A. De Vogüé, Sources Chrétiennes 260 (Paris, 1979), book III, ch. 19, pp. 346-348).

79 The Roman history of the city - and even its pagan past - is praised in the Versus de Verona, ed. G. B. Pighi, Versus de Verona, Versum de Mediolano civitate (Bologna, 1960) p. 152, vv. 1-24.

${ }^{80}$ On the cult dedicated to Zeno in Verona along the Middle Ages (with a main focus on the hagiographical literature) see E. Anti, Verona e il culto di san Zeno tra IV e XII secolo (Verona, 2009).

${ }^{81}$ Many Italian scholars have written on the Bolognese cult dedicated to Vitalis and Agricola, for a general overview see the articles gathered in G.P. Ropa and G. Malaguti (eds.), Vitale e Agricola sancti doctores. Città, Chiesa, Studio nei testi agiografici bolognesi del XII secolo (Bologna, 2001); G. Fasoli (ed.), Vitale e Agricola. Il culto dei 
protomartiri di Bologna attraverso i secoli nel XVI Centenario della traslazione (Bologna, 1993); A. Donati (ed.), Vitale e Agricola: un cammino di fede. Atti del convegno nel XVI centenario della traslazione delle reliquie, Istituto per la storia della Chiesa di Bologna. Saggi e ricerche, 8 (Bologna, 1997).

${ }^{82}$ Ambrose of Milan, Exhortatio Virginitatis, PL 16, cols. 335-364.

83 This mistaken attribution has recently been studied by the French scholar Cécile Lanéry who persuasively demonstrated not only the groundless reference to Ambrose, but also the inconsistency of one of the two versions of the Passion, a "Passion fantôme” made up in the modern period by an enterprising $16^{\text {th }}$ century Roman editor. See C. Lanéry, Ambroise de Milan hagiographe, Collection des Études Augustiniennes. Série Antiquité 183 (Paris, 2008), especially on the hagiographical dossier dedicated to Vitalis and Agricola pp. 445-464.

${ }^{84}$ There territories were first annexed in 751 by the Lombard king Aistulf and then redeemed by Pippin, king of the Franks, and donated to the Roman popes in 756.

${ }^{85}$ On the African religious dissent in the early Christian period see W.H.C. Frend, The Donatist Church: a Movement of Protest in Roman North Africa (Oxford, 1952).

${ }^{86}$ Cf. note 11. 
${ }^{87}$ On the absence of a female sanctity south of the Alps and the Loire see J.M.H. Smith, 'The Problem of Female Sanctity in Carolingian Europe (c.780-920)', Past and Present 146 (1995), pp. 3-37, on the geographical distribution of the Carolingian hagiography o n women saints esp. p. 9. On the absence of an Italian female sanctity in the early Middle Ages see C. La Rocca, 'I silenzi dell'agiografia. La mancanza di sante in età longobarda', in A. Tilatti and F.G.B. Trolese (eds.), Giustina e le altre. Santi e culti femminili in Italia settentrionale dalla prima età cristiana al secolo XII (Roma, 2009) pp. 163-174.

88 See Ex historia translationis Sanctae Pusinnae, ed. G. H. Pertz, MGH SS II (Hanover, 1829), pp. 681-683.

${ }^{89}$ De vita et meritis, ed. P. Courcelle, p. 67 : 'toto desiderio praeoptans martyrium si non defuisset percussor.' Also ibidem, p. 103: 'unde licet ratio ei temporum non potuerit praestare martyrium, gloria tamen martyris non caret, qui voto et virtute quidem potuit esse martyr et voluit, si non defuisset percussor.'

90 The early medieval epic legend of Faustinus and Iovita of Brescia (BHL 2836) featured the two main Christian characters among other minor saints. The hagiographers rewriting this legend in the late eighth or early ninth century obviously focused on the main pair (Faustinus and Iovita), but they also decided to save short sections of the original, extremely long, Passio concerning those saints whose connections with the episcopal church of Brescia were stronger (the local bishop Apollonius and the martyrs Afra and Calocerus), see G. Vocino, 'Santi e luoghi santi’, pp. 78-85. 
91 The record of late-antique public offices or names of geographical provinces can often be held as a hint for an early dating of the hagiographical account or, at least, for the existence in the text of an earlier layer, see P. Tomea, 'Agni sicut nive candidi' pp. 28-29. 